\title{
Rumah Tinggi of Korowai Tribe, Papua: Material and Technology Transformation of Traditional House
}

\author{
Dalhar Susanto ${ }^{1, *}$, Dini Puti Angelia ${ }^{1}$, and Kevin Aditya Giovanni Suhanto ${ }^{1}$ \\ ${ }^{1}$ Department of Architecture, Faculty of Engineering, Universitas Indonesia, Depok, Jawa Barat
}

\begin{abstract}
Traditional dwelling in Indonesia is about to change and lead the threatening of extinction that coming from both of inside the community. It is because social and cultural growth in the society tends to dynamic and changes following the globalization and technology development. Technology advances also make a change of function and form of Rumah Tinggi of Korowai tribe. Traditionally, the building process of Rumah Tinggi involves the community, from harvesting the material from nature, processed, assemble to completion. Currently, the function of Rumah Tinggi starts do transform because of material development and construction technic. Material acquisition processes are no longer done manually and communally by indigenous people but have been changed in construction techniques. This Paper describes the resultant of Research aimed to record the transform of Rumah Tinggi of Korowai tribe process. Construction of Rumah Tinggi of Korowai tribe has been relying on traditional technology - manual has been replaced by modern construction techniques involving material, tools, and new method. It discussed four aspects, materials; construction; tools; and distance, using qualitative methods through observation and field interviews, conducted in 2017 which the elaborated with several literature studies.
\end{abstract}

\section{Introduction}

"Vernacular architecture is non-high style building; it is those structure not designed by professionals; it is not monumental, it is unsophisticated...." (Rudofsky, 1964). Vernacular architecture comes from humans' response to survive and settle in their contexts with long hereditary periods of time. The trial and error process takes place regarding this [6]. Vernacular architecture is often referred to a form of sustainable architecture because it is formed by the engagement between human needs of inhabitants with its surrounding environment [3,6,12], related to natural resources available in the area as well as its geographical condition. Shape and forms of the vernacular architecture are people built it themselves using traditional technology with available natural resources in their environmental context [7].

\section{Vernacular Dwelling Forms of Korowai Tribe}

Settling tradition in Indonesia is strongly influenced by two factors: natural environmental conditions (landscapes, climate, and natural resources), as well as sociocultural environments including belief, economy, technology, social organization, and community politics. These factors influence the way humans formulate and implement a classification system, and perspective of life that is then used as the basis of organization, materials, rules, order, construction, and the division of space and tribal rituals.

"Although changes over time are to be seen in most building traditions, the persistence of distinct and distinctive building types and forms, of material resources and methods of construction, and of space use and associated values are undeniable." (Paul Oliver, 2006). Dynamic changes and developments will take place simultaneously with the changes in vernacular community livelihood patterns. Therefore, many traditions that carried hereditary begin to lose their value over time. There are some changes in vernacular settlements that we can observe such as the type and shape of the building, material resources, construction methods, and spatial function.

Korowai is a tribe that lives in a swampy rainforest and spread in some areas in Papua Island. They live by hunting and gathering and embrace their traditional system of giving and take [8], and traditional law run above the government's law. Therefore, it often becomes a trigger of tribal war. Korowai is famous for their architecture that has a fantastic elevation, it is called Rumah Tinggi. According to Rupert Stasch [9], Korowai's Rumah Tinggi has about fifteen feet of elevation from the ground and stands on several tree trunks as its structure. Besides, the distance between these Rumah Tinggi is also very far apart. "Korowai build their houses standing alone or in pairs, often about a mile from the next occupied house clearing." (Stasch, 2013). Korowai's Rumah Tinggi is a form of response

\footnotetext{
*Corresponding author: dalhar3001@yahoo.com,
} 
from Korowai people to its geographical context, a low swampland riverbank area between two rivers, where flood frequently take place [4]. Korowai's Rumah Tinggi stands on the primary structure made of Wamboon Tree or Banyan tree and supported by several pillars in its corners.

This paper will focus on the transformation that occurs in Korowai's traditional architecture, especially Korowai's Rumah Tinggi. Oliver [6] said that there are some aspects of changes regarding vernacular settlements. In this paper, the transformation will be examined focus on the changes and development of materials and technology used in making their house. The transformation aspect is related to the material and availability of resources used in making the house so that the distance required to obtain the material is also our consideration in this study. Construction methods, tectonics, and tools that they used; the number of people who helped in making Rumah Tinggi is also an aspect that will be used in this paper.

\section{Methodology}

This paper uses qualitative methods in the development of research data that took place in 2017 on the Korowai land in Yafufla Kampong, Yaniruma district, Papua. In this paper, the authors will focus to explain the transformation of the materials used and technology from Korowai traditional house. All the results of the paper will be supported by literature studies, with supporting theories. In this qualitative method, data are obtained by observation and interview. For this study, there are several ways that the author has done, including data collection as much as possible, analysis and interpretation. In this paper, the author tries to observe how Korowai's Rumah Tinggi forms, especially the materials and technology used by the Korowai people and also the transformation that has occurred. These data will be analysed based on five aspects, natural resources, human resources, construction techniques, tools that used, and the distance to retrieve the material. The result of this paper is an interpretation of the authors based on data collected in field research in 2017 by elaborating several literature studies.

\section{Study Case and Analysis - Material and Technology Transformation of Korowai Tribe Traditional House}

Korowai tribe is known with the settlement on the top of a tree and some of the pole wood as sustained construction. Whereas Korowai tribe known as their Rumah Tinggi, there are three kinds Haim of traditional house of Korowai in several functions; Rumah Tinggi as a dwelling place; Tree house as dwelling place when wartime; and Bivak as temporarily settle during Rumah Tinggi construction. From the three type of Korowai settle, two types of houses except the Bivak built on the tree because of the geographic condition in Papua, especially in Yafufla Kampong is swampy forest flanked by two large rivers. When monsoons the water will increase to the forest, and become the flood. However, their house can be saved because of the elevation (fig. 1). All of the materials that are used in Bivak, Rumah Tinggi, and tree house are from the forest, so it makes easy to get and carry.

Base on location in the tropical country, partly of geographic form in Papua is the swampy area, and it has a wet and dry part depending on the weather. In the dry part, there has a big tree that can be the main structure of Rumah Tinggi. Moreover, in dry part, the land can be sago field. Besides sago can be as food ingredients, a part of the sago tree is moulding the material of houses elements. For the next explanation will describe the transformation of architecture element from the transformation aspects (material used, construction technique, tools, and distance).
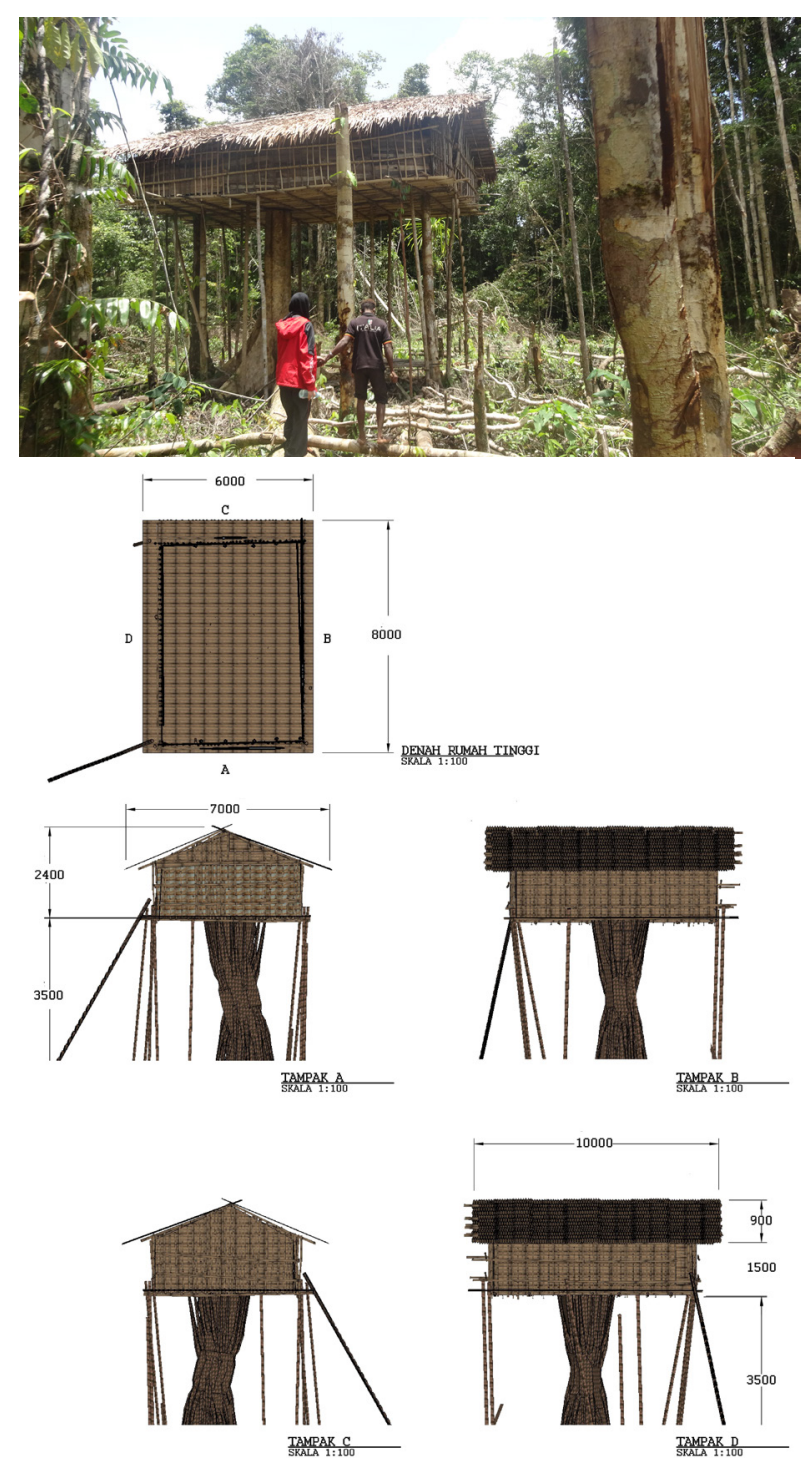

Fig. 1. Rumah Tinggi elevation.

A Rumah Tinggi construction is the responsibility of Korowai men, especially for the head of household. The number of people who can join in the construction process depends on the number of family members. For 
someone who has a member of a family will get help from his son, brothers, and another man that has the kinship. The woman cannot help in the build process. However, the woman will help to look for the materials in the forest, like sago leaf, rattan, and foods.

\subsection{Hohul or tree as main structure}

Hohul is a tree trunk cut down at the top, while the root part of its middle is maintained to be the main structure in the Rumah Tinggi. Korowai's ancestor using Wamboon or Banyan trees as the main structure of their house $[4,5]$. For the materials selection, there is no specific ritual performed in the selection of trees, but the strength of its roots and trunks hold the load. This concept of selection still performs today, but now it does not utilize a Banyan tree, any tree that has strong roots and stems can be developed to create a structure. There is a massive change in the tools used to cut down trees. Formerly, the elder used stone axes to cut the tree. Now, since the entry of new material in the form of iron, cutting trees becomes easier in Korowai. Although the iron axe has shifted the use of stone axe, the construction technique remains used manual human power and knowledge.

\subsection{Para-para and stairs}

After the Hohul ready, the process followed by creating para-para which is aimed to be the temporary structure (fig. 2). Para-para is the horizontal surface that functions as either the main or temporary base for a stand. It is made of Kayu Buah or twig with the vertical support of another twig to the horizontal part.

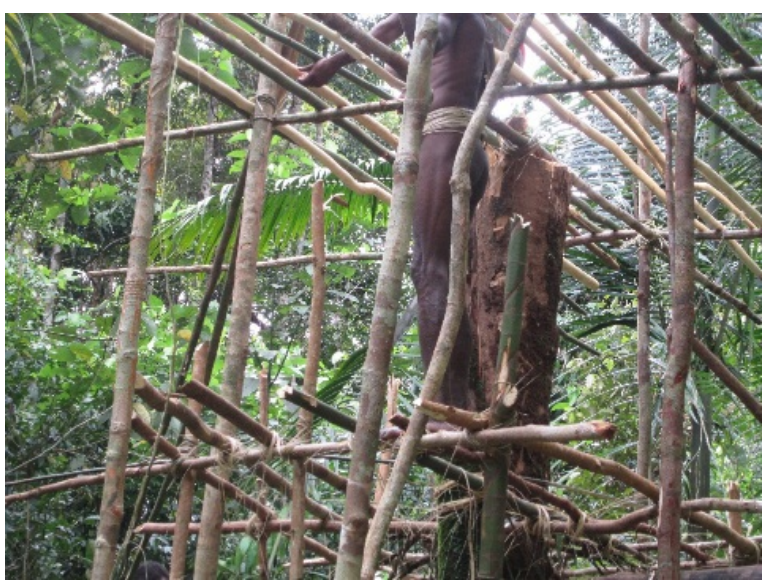

Fig. 2. Para-para as temporary buffer.

\subsection{Binding materials}

The main material of Rumah Tinggi is round wood (fig. 3 ) using rattan as the binding material between wooden interconnection. Although the inclusion of intervention into Korowai causes them to recognize nails as a connecting material, they do not apply when building a Rumah Tinggi. In addition to house construction, rattan is also used as a binding material in everyday tools, such as sago pangkur tool, arrows and arrows, and other tools. In the manufacture of houses, rattan is used as a binder of the overall wood forming the house.

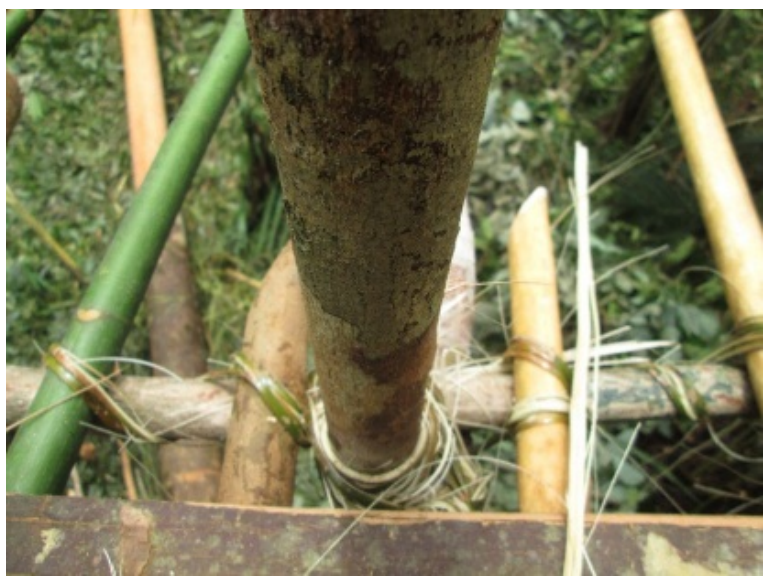

Fig. 3. Rattan rope used.

Meanwhile, there is another material used for the rope, it called with Mangkok or Merah rope (fig.4). The wrist strap is made in a wet state because it is already dry the textured rope will harden and difficult to tie. However, when it is utilized at the house, the Mangkok rope has hardened. Visually we can distinguish wet and dry ropes. If it is still wet, the Mangkok rope will be white ivory, whereas if it is dry will change the colour to red.

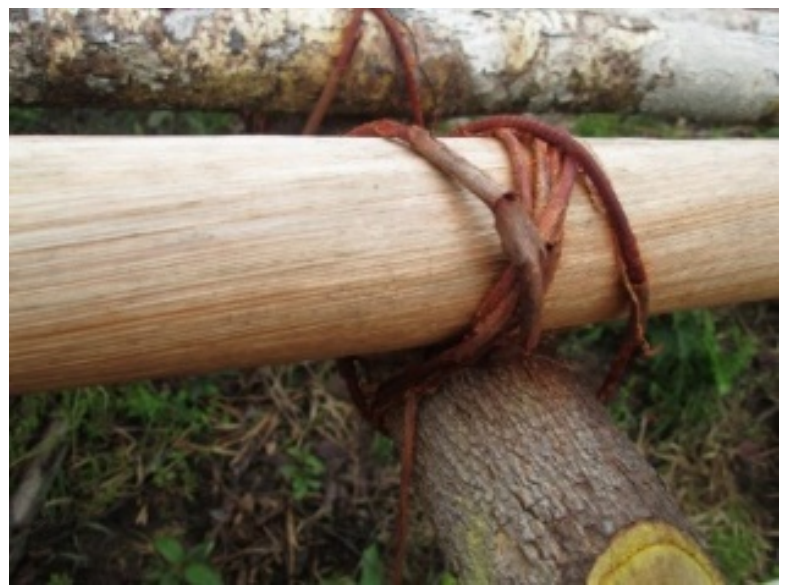

Fig. 4. Tali Merah or Tali Mangkok used.

\subsection{Floor structure and additional columns}

After the para-para created as temporary supports on the main structure tree, a binder beam is formed in a shape perpendicular to the main tree. After the primary beam is made, it continues with creating the columns that will help direct the distribution to the ground using the Kayu Buah. Additional columns here will be used as a dealer from the roof to the ground (fig.5). 


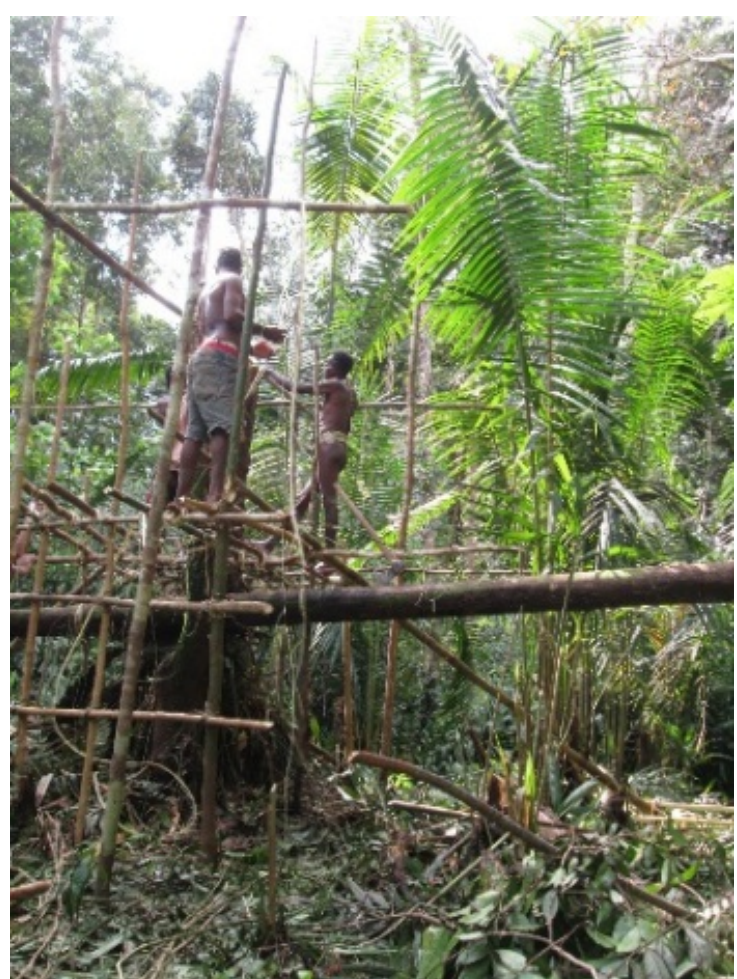

Fig. 5. Floor Structure and additional columns.

The number of beams and columns are adjusted to the height of the Rumah Tinggi. Then after the main beam and additional columns are made, it will be continued by adding the supporting beams used as a floor-proofing material. The all of the structure will be connected with the rattan rope.

\subsection{Structure and roof-covering}

After the main structure of the Rumah Tinggi is done, it continues with constructing the roof structure (fig. 6). Firstly, it starts by making the trestle of the roof structure with additional columns. After the trestle is made, it follows by building the rafters using Кауи Buah as well. The distinguish use of Kayu Buah lies only in size because it is adjusted to the difference in strength to withstand the load.

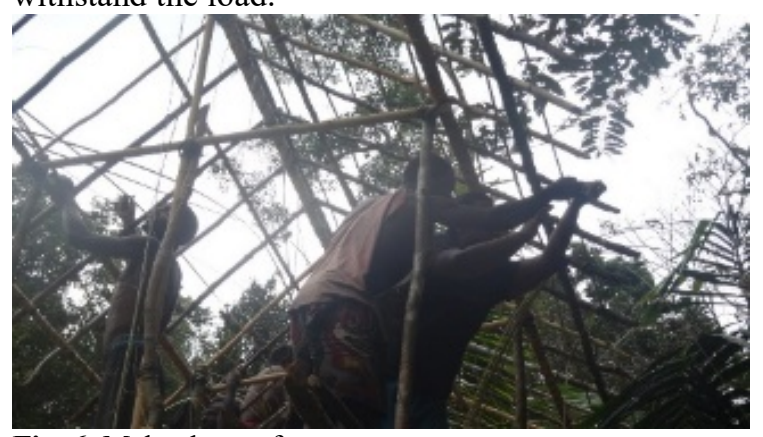

Fig. 6. Make the roof structure

The Rumah Tinggi roof cover is using a sago leaf that is folded and arranged by the insertion method (fig. 7). The insertion treatment is used because of sago leaves need as a roof cover directly attached to the roof structure so that the material needs can be adjusted to the height of the house. Because it is directly attached to the structure of the roof, so it must add a batten made of rattan pieces on the rafters and later sago leaves that have been folded, they are inserted into the battens that transverse from tip to tip of the roof.

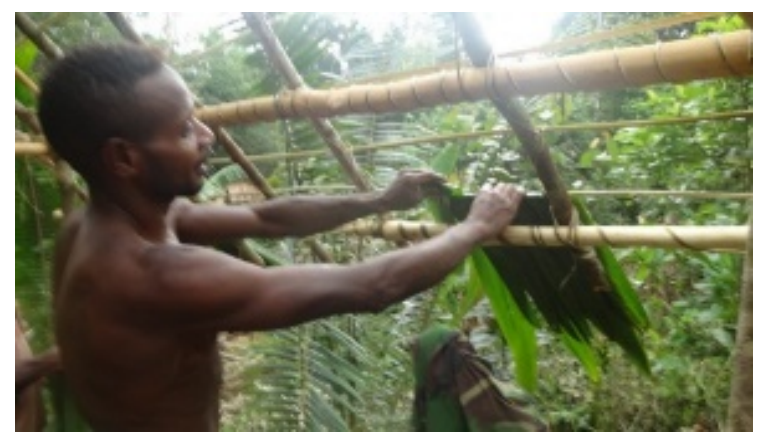

Fig. 7. Roof covering with insert system.

\subsection{Ulahal (floor-covering)}

There are several ways and materials used to create the ground cover surface. The explanation of the flooring will be divided based on the type of material used.

A. Tree barks

The bark is a material that is often used as ground cover surface material in Rumah Tinggi. Trunks of trees felled before it is hulled by pounding the bark to make easy during the process of debarking. The size of the bark is adjusted back to the needs and size of the house.

After wholly peeled, the barks are taken to the Rumah Tinggi and be spread on an additional beam like a carpet (fig. 8). This surface will be adjusted again to fit the shape of the Rumah Tinggi by cutting with an axe.

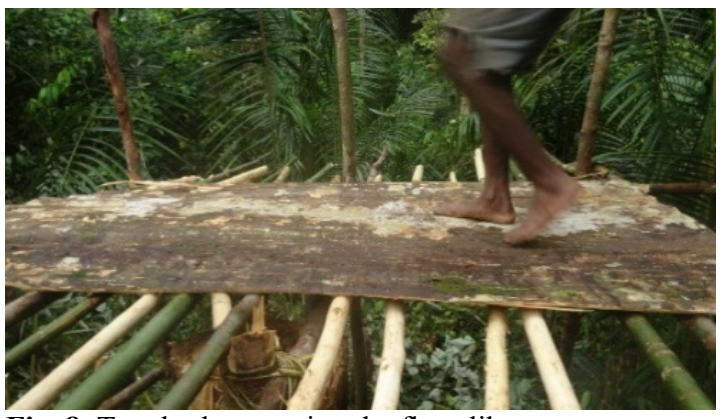

Fig. 8. Tree barks covering the floor like a carpet.

\section{B. Nibung Barks}

Nibung is a palm tree that can be installed as floorcovering. Nibung has several processes; the first one is cutting the tree trunk. Then the trunks will be split into several parts that will be pounded as flat as they could. Next, this flattened Nibung will be placed on top of the beam and assisted with the binder material such as rattan or Merah rope (fig. 9). This process is repeatedly done, then the rattan will be tied to each meeting beam with Nibung wood so it will be tight and well attached. 


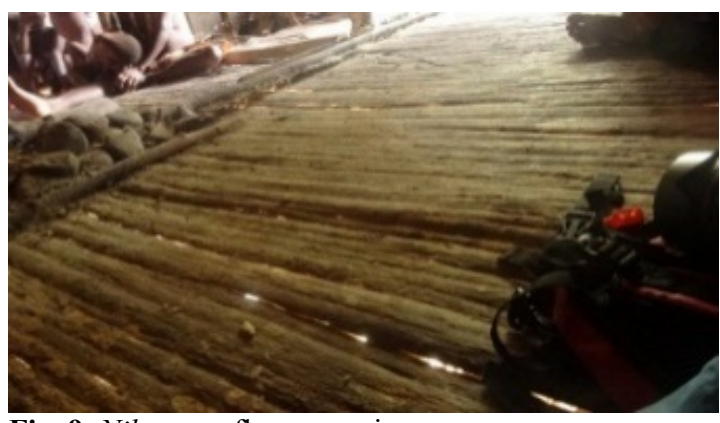

Fig. 9. Nibung as floor-covering.

Nibung has more extended durability than bark. It makes Nibung a priority choice and frequently used as flooring than bark on the Rumah Tinggi. However, the installation process of Nibung is longer, and it needs more skill in Korowai craftsmanship because it must be tied piece by piece of Nibung to support the beam with rattan.

\subsection{Wall}

The last phase of constructing a "Rumah Tinggi" is filling the wall surface. The wall is constructed as the last part because before the wall is made, there will be the manufacture of poles supporting the wall from roof to floor structure. The usage material to be a supporting pole is a Kayu Buah which the size has been adjusted previously. Then, it is tied to the tip of the rafters, or local language Atelil to the end of the floor block called a Dil using rattan.

After the wall mounting pole is placed, the next material to be installed in the wall cover or "leam" in Korowai. Two materials are used as leam, including sago and bark barks.

A. Sago midrib

Sago midrib is widely used for some daily needs by the Kombay-Koroway people. The examples of the use can be seen in the process of "Ramas Sagu," and we can also find as wall-forming material. Sago midrib, which will be flattened to thin and flat, are used to be wall filler (fig. 10). It is a flat sago midrib to make it easy to insert the wall filler supporting twig structure. This sago midrib will be inserted correctly to the cross-system wall filler supporting twig structure until these materials thoroughly cover all the surface.

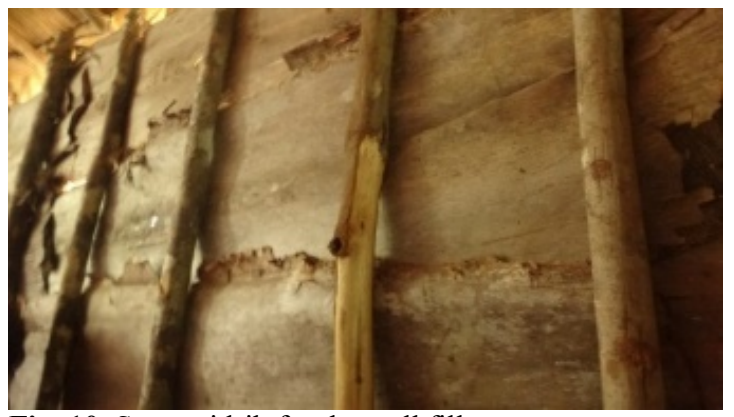

Fig. 10. Sago midrib for the wall filler.

Besides being used as floor cover material, bark can also be installed as wall cover material. A bark from "Damar Hutan" frequently used as floor and wall cover. The installation method is the distinction between those two parts. If the installation of the bark cover part has been peeled and crushed, it is just rolled up like a mat, while on the wall filler, the bark is inserted between the supporting structures as a way of installing sago midrib.

From the material that is used for this wall filler, the sago sap is easily inserted to obtain because it is used a dry sago heap that falls from the sago tree as it grows, and the sago tree is commonly found in the hamlets of the Koroway society. Also, if using bark, the remaining trees are not skinned just left. After it dries, it is just cut into small pieces and used as firewood. Sago midrib is more often used as wall filler because it is easier to obtain. Besides, based on the continuity of the amount of material, sago midrib sap is more sustainable because there are many and always planted by Kombay-Koroway tribe people to meet their food needs.

\section{Finding}

From the description above of Rumah Tinggi transformation. We focused on material and construction. There are analysis results of all transformation aspects in Rumah Tinggi component.

Table 1. Transformation of Rumah Tinggi.

\begin{tabular}{|c|c|c|c|c|c|}
\hline $\begin{array}{l}\mathrm{N} \\
\mathrm{O}\end{array}$ & Component & $\begin{array}{c}\text { Materia } \\
1 \text { Used } \\
\text { Change }\end{array}$ & \begin{tabular}{|c|} 
Constru \\
ction \\
Techniq \\
ue \\
(Manua \\
l/Machi \\
ne)
\end{tabular} & Tools & Distance \\
\hline 1 & $\begin{array}{l}\text { Hohul/ main } \\
\text { tree based }\end{array}$ & - & Manual & $\begin{array}{l}\text { Change from } \\
\text { kapak batu to } \\
\text { axes }\end{array}$ & \multirow{7}{*}{$\begin{array}{l}\text { Material } \\
\text { source is } \\
\text { around from } \\
\text { Korowai's } \\
\text { boluf in the } \\
\text { forest. }\end{array}$} \\
\hline 2 & $\begin{array}{c}\text { Para-para } \\
\text { and Stairs }\end{array}$ & - & Manual & $\begin{array}{c}\text { Change from } \\
\text { kapak batu to } \\
\text { axes }\end{array}$ & \\
\hline 3 & $\begin{array}{l}\text { Binding } \\
\text { Materials }\end{array}$ & - & Manual & $\begin{array}{c}\text { Change from } \\
\text { kapak batu to } \\
\text { machetes }\end{array}$ & \\
\hline 4 & \begin{tabular}{|c|} 
Floor \\
structure and \\
additional \\
columns \\
\end{tabular} & - & Manual & $\begin{array}{l}\text { Change from } \\
\text { kapak batu to } \\
\text { axes }\end{array}$ & \\
\hline 5 & Roof structure & - & Manual & $\begin{array}{l}\text { Change from } \\
\text { kapak batu to } \\
\text { axes }\end{array}$ & \\
\hline 6 & Flooring & - & Manual & $\begin{array}{l}\text { Change from } \\
\text { kapak batu to } \\
\text { machetes }\end{array}$ & \\
\hline 7 & Wall & - & Manual & $\begin{array}{l}\text { Change from } \\
\text { kapak batu to } \\
\text { axes }\end{array}$ & \\
\hline
\end{tabular}

Overall, we found that there is not significantly changed from the material used and technology in Rumah Tinggi, except tools that are used to get the 
materials in the building process. The material used is the same; the technique of construction is still manual, it means that the connecting for the materials are still with rattan or Tali Merah in tie-system; Nothing difference in distance to obtain the materials because all of the objects that are needed are still available in the forest;

Meanwhile, it takes effect to the embodied energy of the building. Using the natural material and manual construction, the energy consumed for material delivery and transportation is low. After building production, which means when the human lives in the building for five until seven years the Rumah Tinggi, finally, it will be abandoned. The former of Rumah Tinggi will be broken and blend into the ground. Therefore, the construction process of Rumah Tinggi is sustainable for the environment.

The change level in the material used depends on materials available in the forest when constructing process. For example, floor materials have a priority level from sago midribs - Nibung bark - tree barks. Besides materials endurance, it is also related to material strength to make a sound when hit. It has done since a long time ago. Moreover, the change process depends on the environment condition in a specific time.

Furthermore, the distance also affects the change in material used and technology by Korowai. Because of resettlement, the distance of each person to their forest (Boluf) becomes different, so it requires to take the house materials further than making a Rumah Tinggi which in the forest. In the resettlement house, we found a new technique of construction in making roof covering. Making a Rumah Tinggi uses a live-inserted system. However, the roof in the kampong uses a modular woven-system (fig. 11). It makes easier for Korowai people in adjusting the material to be used. Moreover, making sago's roof with modular system causes the repairing process easier than the traditional way.

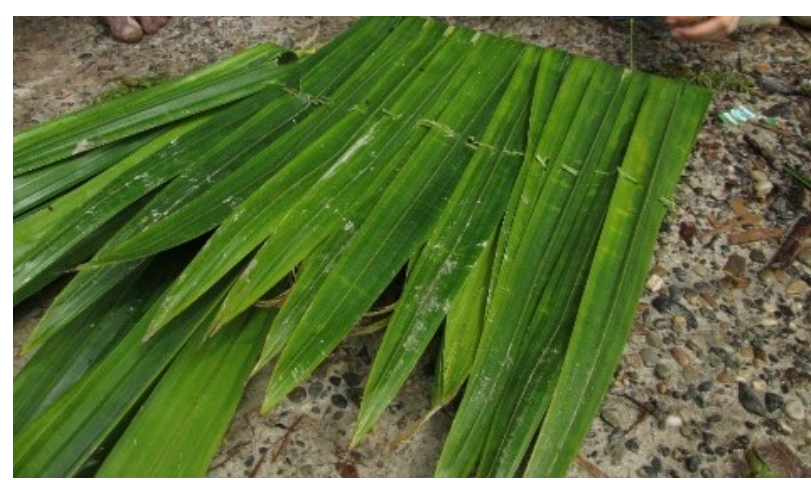

Fig. 11. Roof-cover's new system in kampong.

In material used and construction of Rumah Tinggi, an aspect that significantly influences in transformation is new technology that comes in, especially the introduction of iron tools as the machete and iron axe. The advantage of using the modern tool is the efficiency of time due the faster than tools from stone and bone.
Traditional houses of Korowai tribe, especially Rumah Tinggi is a traditional dwelling form resulted from Papua's geographic that response in the swampy lowland. Moreover, it is flanked by two large rivers that causes a flood if the river water overflows. The intervention into the Korowai society led to the transformation of the Rumah Tinggi in several aspects, the material used, construction technique, tools used, and distance.

The entry of technology to Korowai makes the tools used has changed. Formerly, they used stone axes and bone knives, but now they use iron tools, such as iron axes, machetes, Pangkur tool, and other daily tools. So even though the intervention enters in Rumah Tinggi building process, terms of the material used, construction techniques, and distance are about the same. The transformation change comes from the tools used. Therefore, we can conclude on the Korowai tribe that the inclusion of new technology is very influential in their daily life. The machete or the entry of iron into the Korowai tribe society is a turning point in technological change, and it affects the time efficiency.

\section{References}

1. A. Rapoport, House Form and Culture - Prentice Hall (1969)

2. B. Rudofsky, Architecture Without Architect (1964)

3. Heidegger, Building Dwelling Thingking, Poetry, Language, Thought (1971)

4. M. John, Handmade Houses \& Others Buildings The World of Vernacular Architecture, Thames \& Houdson, 116 (2010)

5. M. Kambuharumba, Interview in Yafufla, Papua (September 2017)

6. P. Oliver, Built To Meet Needs: Cultural Issues in Vernacular Architecture, (2006)

7. P. Oliver (1997)

8. R. Stasch, Society of Others: Kinship and Mourning In A West Papuan Place, 1 (2013)

9. R. Stasch, Society of Others: Kinship and Mourning In A West Papuan Place, 4 (2013)

10. R. Anthony in M. John, Handmade Houses \& Others Buildings The World of Vernacular Architecture, Thames \& Houdson, 6 (2010)

11. S. Sendek, Interview in Yaniruma, Papua (September 2017)

12. T. H. Panjaitan , Hybrid Traditional Dwellings: Sustainable System In The Customary House In Ngada Regency, in IJTECH, 8, No 5 (2017)

\section{Conclusion}

